\title{
The Effect of Sustainability Report on Financial Performance and Corporate Value (Case study on companies participating in ASRRAT for period of 2015-2019)
}

\author{
Akbar Fadillah ${ }^{1}$, Rindah Febriana Suryawati ${ }^{2}$ \\ \{akbar fadillah78@apps.ipb.ac.id, rindah.suryawati@apps.ipb.ac.id $\left.{ }^{2}\right\}$ \\ Faculty of Economics and Management, IPB University ${ }^{1,2}$
}

\begin{abstract}
Corporate Social Responsibility (CSR) is a strategy of alignments between the company, the community, and the environment. The disclosure of CSR activities through the Sustainability Report has been found to influence on the financial performance and value of the company itself. However, some previous researches showed inconsistent results. Asia Sustainability Reporting Rating (ASRRAT) is a form of appreciation for companies that have been implementing and reporting on their CSR activities granted by National Center for Sustainability Reporting (NCSR). Descriptive analysis and Structural Equation Modelling Partial Least Square (SEM PLS) used to analyze the hypothesis. . The purpose of this study is to analyze the correlation of sustainability report with financial performance and value performance of a company. This study shows that the sustainability report has a positive and significant impact on financial performance but has no significant effect on corporate value. Corporate value was positively and significantly affected by financial performance
\end{abstract}

Keywords: Asia Sustainability Reporting Rating (ASRRAT), corporate social responsibility (CSR), corporate value, financial performance, sustainability report.

\section{Introduction}

Social responsibility in business has experienced several changes and faced rapid development every year. Companies are expected to maximize profitability for shareholders and demanded by stakeholders to maintain environmental, social, and governance aspects. These are the main values to be achieved in a company [1]. These values aim to prepare the company to compete with its competitors and maintain its business and operational activities for the long term.

Companies also are expected to minimize impacts generated from their operational activities in both direct and indirect natural resource utilizations. 
One method to reduce these impacts is by executing social responsibility activity. This activity is a form of a company's concern towards society and the surrounding environment [2]. This boosts the company's image and the company's competitive superiority source [3].

The triple bottom line concept is an accounting approach used in the sustainability report arrangement process that corresponds to the sustainable development concept [4]. The triple bottom line concept can be used as the framework in measuring and creating a report involving economic, social, and environmental parameters. This concept can be established as a guideline for all sequences of value, problem, and process to be conducted by a company to minimize negative impacts generated from its operational activities [5].

The execution of corporate social responsibility (CSR) in Indonesia is called social and environmental responsibility (tanggung jawab sosial dan lingkungan/TJSL). Following the implementation of Law of Republic of Indonesia No. 25 of 2007 regarding Capital Investment and Law No. 40 of 2007 regarding Limited Company article 66 and article 74, TSJL activities are an obligation for a company In Indonesia. The core of the law is that all companies are obligated to conduct TJSL activities. TJSL activities execution pays attention to compliance and fairness, and companies who do not execute TJSL activities will be charged with sanctions according to the applied law.

Institute of Indonesia Chartered Accountants (Ikatan Akuntan Indonesia/IAI) and National Center for Sustainability Reporting (NCSR) since 2005 have been conducting an annual activity called Indonesia Sustainability Reporting Award (ISRA) that now changes its name into Asia Sustainability Reporting Rating (ASRRAT). ASSRAT's activities generally aim to appreciate companies in Indonesia who execute and report their CSR activities through the sustainability report. Participants in ASRRAT activities are not only Indonesian companies but also companies from Malaysia, Bangladesh, the Philippines, and Singapore.

Several studies showed that the sustainability report affected to financial and value performances of a company. Nevertheless, until recently, this result has not suggested a consistent result. The CSR activities report (sustainability report) affected the financial performance of a company [6]. This sustainability report also affected the market performance seen from the company's value. The sustainability report affected a company's value and supported the market creation theory [7]. However, these two studies are in contrast with several studies. The result study suggested that the CSR report (sustainability report) negatively and insignificantly affected a company's value [8]. Indicators used to examine a company's value is the Tobin's Q ratio. The CSR report (sustainability report) also has an insignificant result towards the financial 
performance with the ROE value as its indicator [9]. From these inconsistent results, the researcher was interested in studying further regarding the correlation of sustainability report with financial and value performances of a company.

\section{Literature Review}

\section{Corporate Social Responsibility}

Social responsibility activities are an action conducted by a company on a sustainability commitment. This action starts with the ethical consideration of a company that focuses on developing the economy. These activities are also followed by an effort to improve the life quality of stakeholders such as employees and their families and the quality of life of the general public. The priorities of CSR activities are human rights, worker rights, environmental protection, relationship with suppliers, society involvement and development, stakeholder rights, CSR activities monitoring, and CSR activities assessment [10].

There are four categories as components in a company's responsibility [11]. Those categories are:

1. Economic responsibilities, a responsibility in the economic sector because a company's business activities commonly create a commodity or service that benefits the general society.

2. Legal responsibilities mean that the public expects a company's operational activities to follow and comply with the applied rules. A legislative institution in society has previously made the rules.

3. Ethical responsibilities mean that the public expects a company to behave politely and morally in conducting its business activities. Business ethics can provide a moral reflection on a company to assess an issue. This assessment can be implemented to discover developing issues in society.

4. Discretionary responsibilities mean that the public expects to gain a benefit and positive impact on the presence of a company. A company can conduct this expectation in executing a volunteering activity.

\section{Sustainability Report}

A sustainability report is a media used in reporting the CSR activity. A company prepares this report as a responsibility to stakeholders and actualizes the vision and aim of a corporation. This report is integrated with the financial statement, and the information within this report includes social reports, environmental reports, and governance [12]. A sustainability report is designed 
to ease a corporation in creating a plan to the means of reporting to external parties that they care about the economy, social, and environmental aspects. There are several guidelines as a reporting standard in the sustainable reporting applied by all industries and organizations, such as Global Reporting Initiative (GRI), UN Global Compact; Organization for Economic Cooperation and Development (OECD) Guidelines for Multinationals; Extractive Industry \& Transparency Initiative (EITI), and SRI (Sustainability Reporting Initiative).

\section{Financial Performance}

Financial performance reflects a company's financial condition that can be executed by assessing specific criteria. Financial performance can also be used to analyze financial ratios in a company's financial statement [13]. Results from the financial performance can be used to discover and assess a company's management performance in one period. These results are also used to evaluate and assess the target achievement previously established [14]. The financial performance in this study focuses on the assessment of profitability and solvability ratios. The profitability ratio can be used to examine and assess a company's success in managing and utilizing their assets and resources while the solvability ratio is used to examine and assess a company's ability in fulfilling their long-term liabilities.

\section{Company's Value}

The company's value is the current value of various incoming cash flows generated by a company in the future [15]. The process of a company's value creation starts with a fluctuating market condition. This condition is affected by the economic condition, government regulations, or competition atmosphere with competitors. This market condition will affect the company's performance. The company's performance is determined by performances of operation, funding, investment, and policies regarding dividends that will decide the company's cash flow. Several indicators can be used to examine a corporate value, e.g., EPS, PER, PBV, and Tobin's Q.

\section{Research Framework and Hypotheses}

\section{Research Framework}

This study used two analysis methods, i.e., descriptive analysis and Structural Equation Modelling method with a Partial Least Square approach (SEM PLS). The descriptive analysis was used to analyze the financial and value performances of a company in study samples. The analysis of the effect 
of sustainability report on financial and value performances of a company was carried out using the Structural Equation Modelling with a Partial Least Square approach (SEM PLS). The framework of this study is presented in Figure 1.

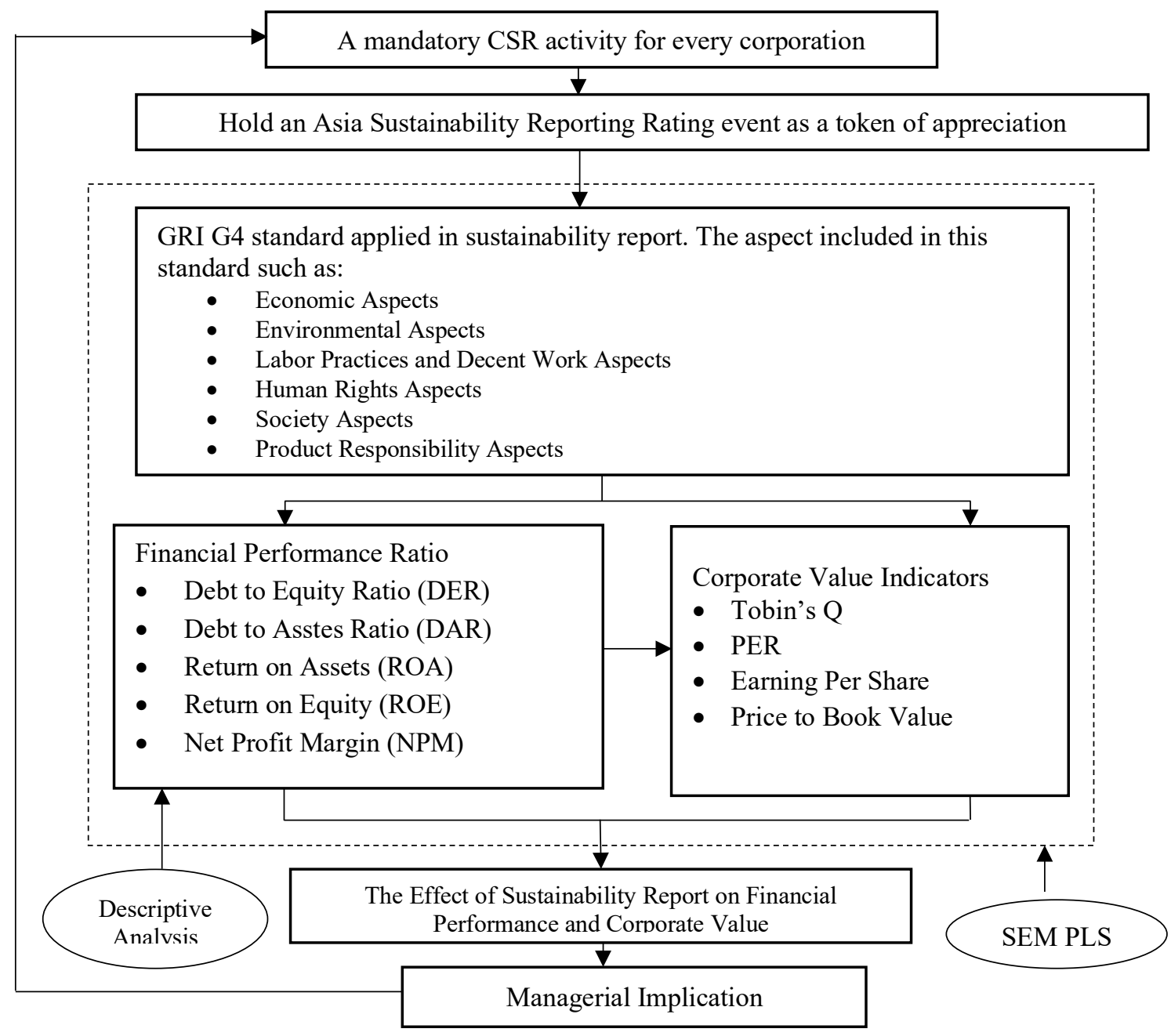

Fig. 1. Research Framework

Objects in this study were companies participating in the Asia Sustainability Reporting Rating (ASRRAT) event from 2015 to 2019. The population of this study was 84 companies. The sampling method used in this study was the purposive sampling method using the criteria determined by the researcher and obtaining a total sample of 28 companies. 


\section{Research Hypotheses \\ Sustainability report affects the financial performance of a company}

According to Purbawangsa et al., [16], a company that cares about the environment has a chance for better performance. This care will generate an impact of positive insight from the public to the company. A company with a consistent improvement in its financial performance will continue to ensure that its social responsibility activity benefits the organization and society. The social responsibility and sustainability report were conducted as an effort by the company to discover and understand its current and long-term targets. This statement follows a study by Oware and Mallikarjunappa [17], as well as by Bhernadha et al., [18]. These studies result proved that the sustainability report significantly affected financial performance. From this statement, then the first proposed hypothesis is:

H1: Sustainability Report (SR) affects the financial performance of companies in study samples.

\section{Sustainability Report (SR) affects the value performance of a company}

There was a correlation between the Sustainability Report (SR) with the company's value [19]. This statement corresponds to the signaling theory. This theory stated that a company is expected to provide information for external parties. The information will affect the company's value reflected from the stock price in the fluctuating capital market. This change is a response from the market to the company for the information and assumes that it is a signal. This statement is also following a statement by Murnita and Putra [20]. They found evidence of the effect between a company conducting the corporate social responsibility activity and its report with its value. From this statement, the second proposed hypothesis is:

H2 : Sustainability Report (SR) affects the value of companies in study samples

\section{A Company's Financial Performance Affects Its Value}

Sihotang et al., [21] stated that a company's performance and value are related. If the financial performance of a company is decent, the company's value will follow. This condition increases the company's value. The profitability ratio can be used as an aspect of assessing the financial performance of a company. This ratio illustrates the ability of an organization or company to efficiently run its business and illustrate its profit in running its business and operational activities. The higher the profitability rate, the higher the value of a company. Increased company's value will affect an investor in investing in the company. This condition impacts the stock price in the capital market to increase, as well. A study by Pohan and Dwimulyani [22] supported the 
statement. Financial performance influences a company's value. Based on the statement, the last hypothesis proposed is:

H3 : The financial performance affects the value of companies in study samples.

\section{Result}

\section{Company's Financial Performance and Value}

This study used 15 indicators, i.e., six indicators for the sustainability report, five indicators for the financial performance assessment, and four indicators for the company's value assessment. The samples in this study are dominated by companies in the finance sector, with a total sample of 9. Compliance of companies in the finance sector in conducting and reporting this sustainability report is caused by the clear rule and the presence of institutions observing their activities. One of the rules is listed in the Financial Authority Services Regulation No. 51/POJK.03/2017 The Implementation of Sustainable Finance for Financial Service Institutions, Emiten, and Public Companies. Furthermore, financial institutions are directly monitored by the Financial Services Authority $(\mathrm{OJK})$ regarding the sustainable finance action plan and sustainability report. This report includes all business sectors listed in the BEI, but not for the various industrial sector. The researcher excluded the Miscellaneous Industry sectors because no company within the sector participated in ASRRAT events between 2015 and 2019. The following company sample distributions based on the business sectors presented in table 1 .

Table 1. Company sample distributions

\begin{tabular}{clcc}
\hline No & \multicolumn{1}{c}{ Business sectors } & Number & $\%$ \\
\hline 1 & Agriculture & 2 & 7.14 \\
2 & Mining & 7 & 25 \\
3 & Basic industry \& chemicals & 2 & 7.14 \\
4 & Miscellaneous undustry & 0 & 0 \\
5 & Consumer goods industry & 1 & 3.57 \\
6 & Property, real estate, and building & 1 & 3.57 \\
& construction & & 10.71 \\
7 & Infrastructure, utility, and & 3 & 32.14 \\
& transportation & & 10.71 \\
8 & Finance & 9 & 100 \\
9 & Trade, service, and investment & 3 & \\
\multicolumn{2}{r}{ Total } & 28 & \\
\hline
\end{tabular}


During five years of observing, the researcher found several companies with excellent financial performance and the company's value. One of them is Unilever Indonesia, that recently obtained the biggest ROA and ROE values compared to other companies in study samples. Both indicators illustrate how far a company receives profits from its assets and equity and illustrate other companies that indicate that the management has effectively conducted its activity by utilizing economic resources within its power. Calculation of financial performance and company value in five years ' rate (2015-2019) presented in table 2 .

Tabel 2. Calculation of financial performance and company value in five years rate (20152019)

\begin{tabular}{|c|c|c|c|c|c|c|c|c|c|}
\hline $\begin{array}{c}\text { Stock } \\
\text { Ticker } \\
\text { Symbol }\end{array}$ & $\mathrm{ROA}$ & ROE & NPM & DAR & DER & EPS & PER & PBV & $\begin{array}{c}\text { Tobin's } \\
\text { Q }\end{array}$ \\
\hline ABMM & 1.42 & 3.79 & 1.38 & 0.79 & 4.39 & 55.27 & 30.10 & 2.36 & 1.22 \\
\hline ANJT & 1.53 & 2.22 & 5.14 & 0.33 & 0.49 & 34.50 & -183.05 & 0.92 & 0.94 \\
\hline ANTM & 0.33 & 0.63 & -0.96 & 0.40 & 0.67 & 4.92 & 110.25 & 0.90 & 0.89 \\
\hline BBKP & 0.35 & 4.37 & 4.02 & 0.92 & 12.11 & 35.20 & 21.62 & 0.62 & 0.96 \\
\hline BBNI & 1.85 & 12.73 & 26.55 & 0.82 & 5.63 & 696.45 & 10.58 & 1.35 & 1.02 \\
\hline BBRI & 2.60 & 18.31 & 28.56 & 0.85 & 6.00 & 579.69 & 13.32 & 2.41 & 1.18 \\
\hline BDMN & 1.81 & 8.41 & 19.33 & 0.79 & 3.71 & 350.65 & 14.33 & 1.22 & 1.05 \\
\hline BJBR & 1.26 & 13.67 & 12.18 & 0.86 & 9.32 & 142.05 & 14.53 & 1.85 & 1.03 \\
\hline BJTM & 2.10 & 14.60 & 21.03 & 0.85 & 6.02 & 77.02 & 8.02 & 1.17 & 1.02 \\
\hline BNBR & -19.00 & 22.61 & -23.06 & 1.38 & 0.39 & -17.17 & -1.67 & -0.42 & 1.83 \\
\hline BNGA & 0.96 & 6.57 & 16.07 & 0.86 & 6.14 & 82.15 & 16.67 & 0.64 & 0.95 \\
\hline BNII & 1.05 & 8.34 & 22.20 & 0.87 & 7.09 & 25.25 & 9.44 & 0.79 & 0.97 \\
\hline BNLI & -0.35 & -3.71 & -8.56 & 0.87 & 6.74 & -31.82 & 21.84 & 0.85 & 0.99 \\
\hline BUMI & -7.73 & 47.86 & -458.7 & 1.28 & 4.13 & -114.7 & 12.45 & 1.15 & 1.45 \\
\hline GIAA & -0.61 & -2.64 & -0.56 & 0.77 & 3.43 & -32.96 & 43.09 & 0.78 & 0.92 \\
\hline INCO & 1.39 & 1.64 & 3.88 & 0.16 & 0.19 & 44.23 & 211.15 & 1.10 & 1.08 \\
\hline INTP & 9.16 & 10.70 & 16.32 & 0.15 & 0.18 & 706.38 & 35.05 & 2.97 & 2.54 \\
\hline ITMG & 12.72 & 17.99 & 9.82 & 0.29 & 0.40 & 2116.7 & 7.47 & 1.32 & 1.23 \\
\hline MEDC & -0.06 & -0.55 & 1.20 & 0.75 & 3.02 & 1.69 & -5.78 & 0.49 & 0.87 \\
\hline PGAS & 3.53 & 7.80 & 7.72 & 0.54 & 1.19 & 139.83 & 23.47 & 1.28 & 1.12 \\
\hline PTBA & 15.91 & 25.25 & 18.86 & 0.37 & 0.62 & 587.27 & 8.63 & 2.12 & 1.71 \\
\hline SMGR & 7.04 & 10.87 & 11.17 & 0.38 & 0.66 & 560.28 & 21.50 & 2.07 & 1.67 \\
\hline TINS & 1.17 & 1.03 & 1.71 & 0.53 & 1.35 & 10.19 & 22.40 & 1.03 & 0.98 \\
\hline TLKM & 9.69 & 17.19 & 15.32 & 0.44 & 0.78 & 187.12 & 20.57 & 3.53 & 2.36 \\
\hline UNSP & -16.46 & -46.7 & -92.38 & 1.12 & -7.87 & -724 & -0.62 & 0.01 & 1.01 \\
\hline UNTR & 8.55 & 15.03 & 11.36 & 0.41 & 0.73 & 2091.7 & 13.16 & 1.87 & 1.51 \\
\hline UNVR & 38.95 & 130.6 & 17.60 & 0.70 & 2.39 & 940.03 & 47.20 & 62.05 & 19.00 \\
\hline WIKA & 3.13 & 9.95 & 5.92 & 0.68 & 2.18 & 158.92 & 14.96 & 1.48 & 1.13 \\
\hline
\end{tabular}




\section{The Effect of Sustainability Report on Financial Performance and Corporate Value}

For the measurement of the sustainability report effect on the financial and value performances of a company, the Structural Equation Modeling Partial Least Square (SEM PLS) method was used. The SEM PLS analysis was conducted in several evaluations as follows:

\section{Evaluation of Outer Model}

The first step in the SEM measurement was to conduct an outer model evaluation. The outer model can explain the relationship between latent variables with each indicator. The measuring model was used to test the construct validity and instrument reliability [23]. The convergent validity test can be seen from the loading factor value of each indicator and the Average Variance Extracted (AVE). A construct is stated as valid and ideal if the loading factor is above 0.7 [24]. Other measurements to be noticed is the Average Variance Extracted (AVE) value. The AVE value illustrates the manifests variability contained within the latent construct. The AVE value should be more than 0.5. If the AVE value is under 0.5, it is considered as inadequate since there are more error variants than indicator variants [25]. Here is the outer model and loading factor of the study before dropping that presented in Figure 2.

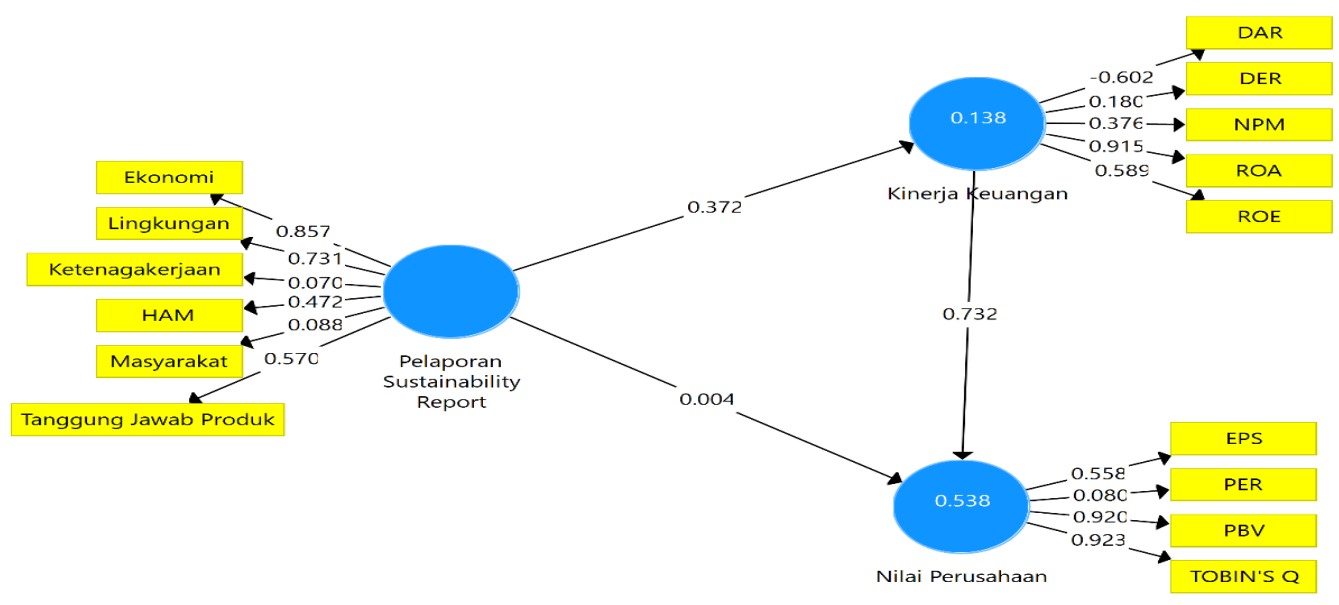

Fig.2. Outer model before dropping

Based on Figure 2, it is visible that ten indicators have loading factor values under 0.7 so that those indicators should be subjected to the dropping of the model. Dropped indicators were the employment of 0.070 , human rights of 0.472 , the society of 0.088 , product responsibility of 0.570 , ROE of 0.589 , NPM of 0.376, DAR of -0.602, DER of 0.180, EPS of 0.558, and PER of 0.080. After 
dropping, the next step was to recalculate to obtain a loading factor value of more than 0.7 and an Average Variance Extracted (AVE) value of more than 0.5 . Here are the outer model and loading factor after dropping that presented in Figure 3 and Average Variance Extracted (AVE) values before and after dropping that presented in Table 3.

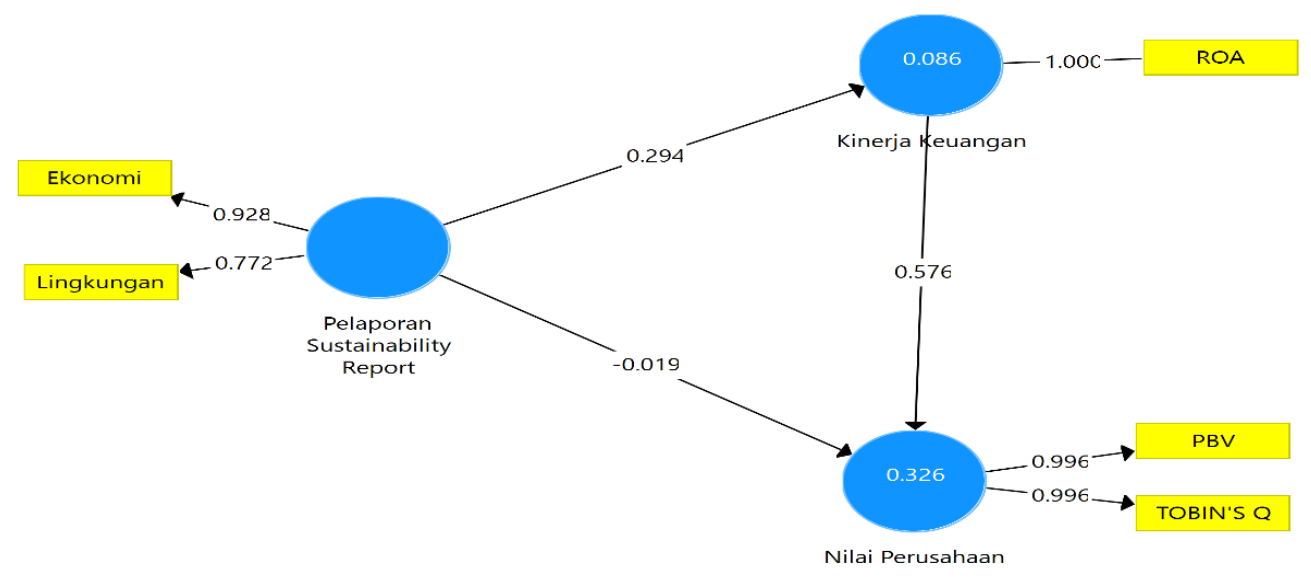

Fig.3. Outer model before dropping

Tabel 3. Average Variance Extracted (AVE) before and after dropping

\begin{tabular}{lcc}
\hline \multicolumn{1}{c}{ Variable } & AVE before dropping & AVE after dropping \\
\hline Financial Performance & 0.344 & 1.000 \\
Corporate Value & 0.504 & 0.992 \\
Sustainability Reporting & 0.305 & 0.728 \\
\hline
\end{tabular}

Before dropping, AVE values for financial performance and sustainability report achieved AVE values of $<0.5$ that shown in Table 3 . After dropping, all variables, including financial performance, company's value, and sustainability report, achieved AVE values of more than 0.5 . It shows that variants accepted by the construct are bigger than variants generated by measurement error so that the model is said to be good. The next step was discriminant validity testing. Discriminant validity testing can be conducted by examining the cross-loading values of each indicator. It aims to ensure that the construct has a sufficient discriminant value. According to Hair et al. , [26] discriminant validity is conducted to illustrate how far the indicator reflects its latent variables. Discriminant validity testing can be seen from the value calculation of other variables, and the cross-loading value should be $>0.70$. The loading values of each indicator with latent variables should be higher than those 
of other variables. The result of the Fornell-lacker criterion value calculation is presented in Table 4, and the result of cross loading value calculation is presented in Table 5 .

Tabel 4. Fornell-lacker criterion value calculation

\begin{tabular}{cccc}
\hline Variable & $\begin{array}{c}\text { Financial } \\
\text { Performance }\end{array}$ & Corporate Value & $\begin{array}{c}\text { Sustainability } \\
\text { Reporting }\end{array}$ \\
\hline Financial & 1.000 & & \\
Performance & & 0.996 & \\
Corporate Value & 0.570 & 0.150 & 0.854 \\
Sustainability & 0.294 & & \\
Reporting & & & \\
\hline
\end{tabular}

Tabel 5. Cross loading value calculation

\begin{tabular}{llll}
\hline \multicolumn{1}{c}{ Indicators } & \multicolumn{1}{c}{$\begin{array}{c}\text { Financial } \\
\text { Performance }\end{array}$} & Corporate Value & Sustainability Reporting \\
\hline Economic & 0.298 & 0.163 & $\mathbf{0 . 9 2 8}$ \\
Environmental & 0.184 & 0.076 & $\mathbf{0 . 7 7 2}$ \\
PBV & 0.579 & $\mathbf{0 . 9 9 6}$ & 0.140 \\
ROA & $\mathbf{1 . 0 0 0}$ & 0.570 & 0.294 \\
Tobin's Q & 0.556 & $\mathbf{0 . 9 9 6}$ & 0.159 \\
\hline
\end{tabular}

The result of cross-loading in Table 5 indicates that indicators of the sustainability report, financial performance, and the company's value had a bigger loading factor value for each measured latent. The result of cross-loading shows that all constructs correlation with measuring items had a bigger value than other constructs, signify that the indicator had reflected latent variables on constructs. On the outer model evaluation, the next step was to conduct a reliability test. Cronbach's alpha and composite reliability values can be used in this step. The lowest acceptance of Cronbach's alpha value is 0.6 [27], and the composite reliability value should reach over 0.7 to continue to the next step. Cronbach's alpha and composite reliability values are presented in Table 6.

Table 6. Cronbach's alpha and composite reliability values

\begin{tabular}{lcc}
\hline & Cronbach's alpha & Composite reliability \\
\hline Financial Performance & 1.000 & 1.000 \\
Corporate Value & 0.992 & 0.996 \\
Sustainability Reporting & 0.648 & 0.842 \\
\hline
\end{tabular}




\section{Evaluation of Structural Model (Inner Model)}

$\mathrm{R}$ Square can be utilized to evaluate structural models. The R Square value may explain the variability of dependent variables that can be explained by independent variables. Dependent variables were financial performance and the company's value. Chin [28] classified the value sizes of R2 that composed of three groups. These groups comprised substantial $(0.67)$, moderate $(0.33)$, and weak (0.19). The result of the R2 value for financial performance was 0.086 , which included in the weak classification. The value result was that the CSR activity execution and reporting by the company were not executed seriously. There are several reporting aspects unreported and unexecuted. Moreover, it is presumed that the company still has doubts about the social responsibility activity execution and reporting because they consider that this activity will decrease the company's profit and that CSR execution has no relationship with the company's business activity improvement. The corporate value variable had an R2 value of 0.326 , which included in the moderate classification.

The next step was hypothesis testing that is visible from the path coefficient result. The original sample shows the relationship direction among constructs. If the original sample value is positive, it will show a positive influence and vice versa. The significance level in the hypothesis testing can be seen from the T-statistics value. The influence is real or significant if the value of t-statistics $>$ t-table. On alpha $5 \%$, the T-table value was 1.96 , and the value of $\mathrm{p}$-value $<$ alpha for $5 \%$. Here is the path coefficient value from bootstrapping that presented in Table 7.

Table 7. Bootstapping

\begin{tabular}{|c|c|c|c|c|c|c|}
\hline & $\begin{array}{c}\text { Original } \\
\text { Sample (0) }\end{array}$ & $\begin{array}{c}\text { Sample } \\
\text { Mean (M) }\end{array}$ & $\begin{array}{l}\text { Standard } \\
\text { Deviation } \\
\text { (STDEV) }\end{array}$ & $\begin{array}{l}\text { T-Statistics } \\
(|\mathrm{O} / \mathrm{STDEV}|)\end{array}$ & $P$ Values & Hypotheses \\
\hline $\begin{array}{l}\text { Sustainability Report -> Financial } \\
\text { Performance }\end{array}$ & 0.294 & 0.300 & 0.047 & 6.230 & 0.000 & Accepted \\
\hline $\begin{array}{l}\text { Sustainability Report }>>\text { Corporate } \\
\text { Value }\end{array}$ & -0.019 & --0.023 & 0.054 & 0.351 & 0.726 & Rejected \\
\hline $\begin{array}{l}\text { Financial Performance -> Corporate } \\
\text { Value }\end{array}$ & 0.576 & 0.579 & 0.114 & 5.033 & 0.000 & Accepted \\
\hline
\end{tabular}

Based on Table 7, hypothesis results of this study are as follow:

The effect of sustainability report to financial performance

This study result shows that the parameter coefficient value or original sample acquired to discover the effect of sustainability report on financial performance was 0.294 , and the $t$-statistic value was 6.230 . It shows that the sustainability report positively and realistically affected financial performance. The first 
hypothesis proposed by the researcher is agreed upon. The sustainability report of a company was not only to fulfill the obligation. The company has realized the importance of the activity and reporting for future performance. Companies that have consistently and sustainably conducted the CSR activity and its reporting will receive benefits. A company's reputation or image is the benefit that impacts positive insight from external parties. With a better company image, consumers will seek the company and be loyal to them. According to Sari et al. [29], a company's good name or image is intangible capital. A customer will expend their money to consume commodities and services created by the company. This condition affects the company's performance, and one of which is the financial performance seen from its profit. A company with a high profit is continuously improving its CSR activity to maintain its reputation and image, and to ensure shareholders that the company has current and future targets. The finding result of this hypothesis is supported by a review conducted by Salehi et al. [30], and Akben-Selcuk [31]. The review results stated that the CSR activity reporting (sustainability report) realistically affecting financial performance with ROA as the indicator.

\section{The effect of sustainability report to company's value}

The results of this study indicate that the value of the parameter coefficient or original sample obtained to determine the effect of sustainability report reporting on company value was -0.019 , and the value of t-statistics was 0.351 . Because the value of the t-statistic was $<1.96$, the second hypothesis proposed by the researcher cannot be accepted. The results of this finding state that the sustainability report and company value do not significantly affect each other. This finding contradicts the signaling theory. This theory explains that CSR activities and reporting affect a company's value significantly, as seen from the stock price. CSR activities and their reporting are used as a good indication given by an investor before investing in a company. This activity is used as one of the considerations made by an investor. This study's results indicate that an investor is not quite sure about CSR activities and their reporting through sustainability reports. When deciding to invest, an investor does not consider this information, and investors pay more attention to other aspects that influence stock prices, such as financial performance or other aspects. An investor pays attention to the information in the form of neural information and accounting information [32]. Investors consider both information to be able to reflect the financial condition of a company so that it can motivate and can be used as a consideration before investing. Investors do not pay much attention to reporting CSR activities because they think that these activities can reduce the dividends they will receive so that an investor's income will decrease. With these results, 
CSR activities and reporting should be done more optimally so that it will have a positive impact on stakeholders and shareholders. Also, reporting on CSR activities must be carried out optimally and comply with predetermined standards. It is expected to help an investor understand and know whether the CSR activities carried out are following the predetermined indicators. These findings are in line with research conducted by Janamrung \& Issarawornrawanich [33]. The study states that there is no influence between CSR reporting and company value.

\section{The effect of financial performance to company's value}

This study's results indicate that the value of the parameter coefficient or an original sample obtained to determine the effect of financial performance on the company's value was 0.576 and obtain a $\neg$-statistic value of 5.033 . Since the value of the t-statistic was $>1.96$, the final hypothesis proposed by the researcher can be approved. These findings indicate that financial performance by the ROA indicator has a positive and significant effect on firm value. This research is in line with the study conducted by Harningsih et al. [34] and Brimantyo et al. [35]. This study examined the influence between financial performance and the company's value. The indicators used were Tobin's $Q$ and PBV values. Financial performance is defined as a reflection of the financial condition of a company in a period. When a company has good financial performance, investors will be interested in investing in that company to affect the stock price and value of a company. The ROA indicator can be used to measure a company's ability to make profits from the assets they own. The greater the value, the more effective and efficient the company is in managing and utilizing their assets to obtain an advantage. The increasing rate of profit will increase the company's stock price on the stock exchange, and an investor is interested in investing in the company.

\section{Conclusions and Recommendations}

\section{Conclusion:}

Based on the research that has been done, several conclusions have been obtained. The following conclusions were drawn according to the research objectives, namely:

1. The sustainability report affects the company's financial performance with ROA as an indicator of its assessment. The results of this study indicate that the implementation of CSR activities and their reporting by a company has a positive impact. One of the impacts is a good image and reputation of the company in the eyes of stakeholders. This condition will 
affect consumers' loyal attitude to a company in consuming the goods and services they create. Consumer loyalty to this company will also affect the company's performance, one of which is its financial performance, which will improve.

2. Disclosure of sustainability report in this study shows different results from the proposed hypothesis. The sustainability report has no effect on firm value in this study. These findings signal that sustainability report reporting is not used as a reference or consideration made by an investor before investing in a company.

3. Financial performance influences the company's value. This study's results indicate that companies that have good financial performance will influence stock prices on the stock exchange. The company's stock price will increase so that the company's value will be even higher. With the increased stock price of a company, an investor will look to a company as a place for them to invest to get a profit from the investment in the future.

\section{Recommendations}

Based on the results of this study, the management of a company must pay attention to CSR activities' activities and reporting through the sustainability report document. Sustainability report is expected to be more detailed in explaining CSR activities and programs and how much the company has incurred costs during one year and not just a brief description in a few paraphrases or sentences. The company is also expected to improve the reporting quality according to the references used in the sustainability report. One example is the GRI standard.

It is hoped that the government will pay more attention to CSR activities carried out by a company by paying attention to the clarity and accuracy of disclosures to assist the state in evaluating and achieving its stated sustainable goals. Together with company management, the government should also hold a meeting to discuss these social responsibility activities so that the program to be implemented is also in accordance with the goals of sustainable development proclaimed by the state. The government should also establish tighter regulations in controlling the implementation of CSR activities so that these activities are carried out and not only to fulfill obligations and carry out firmer law enforcement on the implementation of CSR activities. An investor should also know how to advance the company's financial performance before investing, and stakeholders should also increase their knowledge of CSR activities and reporting.

For researchers who are interested in taking up the same topic as this research, researchers suggest that further researchers choose a sample of other 
companies that have never been studied with the same research topic. Researchers suggest using indicators other than those used in this study and extending the study period, such as ten years, so that it can be seen clearly whether these indicators influence one another. Researchers also suggest using sustainability report reporting standards in addition to GRI G4 standards such as ISO 26000.

Acknowledgments. The authors acknowledge funding support from Department Management of IPB University.

\section{References}

[1] Gunawan J, SeTin. 2019. The development of corporate social responsibility in accounting research: evidence from Indonesia. Social Responsibility Journal. 15(5):671688.

[2] Hadi N. 2011. Corporate Social Responsibility. Yogyakarta(ID): Graha Ilmu.

[3] Myšková R, Hájek P. 2019. Relationship between corporate social responsibility in corporate annual reports and financial performance of the US companies. Journal of International Studies. 12(1):269-282.

[4] Solihin I. 2009. Corporate Social Responsibility: From Charity to Sustainability. Jakarta(ID): Salemba Empat.

[5] Hadad MD, Maftuchah I. 2015. Sustainable Financing. Jakarta(ID): PT Elex Media Komputindo.

[6] Syamni G, Wahyuddin, Damanhur, Ichsan. 2017. CSR and Profitability in IDX Agricultural Subsectors. Emerald Reach Proceedings Series. Vol 1 : 511-517.

[7] Buallay A. 2019. Between cost and value : Investigating the effects of sustainability reporting on a firm's performance. Journal of Applied Accounting Research. 20(4):481496.

[8] Puspaningrum Y. 2017. Pengaruh corporate social responsibility dan kepemilikan manajerial terhadap nilai perusahaan dengan profitabilitas dan ukuran perusahaan sebagai variabel moderating (studi empiris pada perusahaan pertambangan di Bursa Efek Indonesia). Edisi 2:1-14.

[9] Pohan CD, Dwimulyani S. 2017. Analisis pengaruh kinerja keuangan, good corporate governance, dan corporate social responsibility terhadap nilai perusahaan pada perusahaan pertambangan di Bursa Efek Indonesia. Jurnal Magister Akuntansi Trisakti. 4(1):37-54.

[10] World Business Council for Sustainable Development [WBCSD]. 2000. Corporate social responsibility: making good business sense [Internet]. [Accessed on May $18^{\text {th }} 2020$ ]. Available :https:/www.globalhand.org/system/assets/aadd8f32f6ecef3fe3b080b8d462d509da3f3e 57/original/CSR_Good_Business_WBCSD_2000.pdf.

[11] Carroll AB. 1978. A Three-Dimensional Conceptual Model of Corporate Performance. Academy of Management Review 1979. 4(4): 197- 505.

[12] Lako A. 2014. Green Economu: Menghijaukan Ekonomi, Bisnis, \& Akuntansi. Jakarta(ID): Erlangga. 
[13] Fahmi I. 2012. Analisis Kinerja Keuangan. Bandung (ID): Alfabeta CV.

[14] Kasmir. 2010. Pengantar Manajemen Keuangan. Jakarta (ID): Prenada Media Group.

[15] Mardiyanto H. 2009. Inti Sari Manajemen Keuangan : Teori, Soal, dan Jawaban. Jakarta (ID): PT Gramedia Widiasarana Indonesia.

[16] Purbawangsa IBA, Solimun S, Fernandes AAR, Rahayu SM. 2019. Corporate governance, corporate profitability toward corporate social responsibility disclosure and corporate value (comparative study in Indonesia, China, and India stock exchange in 2013-2016). Social Responsibility Journal.

[17] Oware K, Mallikarjunappa T. 2019. Corporate social responsibility investment, thirdparty assurance and firm performance in India: The moderating effect of financial leverage. South Asian Journal of Business Studies. 8(3):303-324.

[18] Bhernadha YA, Topowijono, Azizah DF. 2007. Pengaruh Corporate Social Responsibility terhadap Kinerja Keuangan Perusahaan (Studi Pada Perusahaan Winner of Sustainability Reporting Award (SRA) yang Terdaftar di BEI Periode 2010-2014). Jurnal Administrasi Bisnis (JAB). 44(1): 134-143.

[19] Isnalita, Narsa IM. 2017. CSR Disclosure, Customer Loyalty, and Firm Values (Study at Mining Company Listed in Indonesia Stock Exchange). Asian Journal of Accounting Research. 2(2):8-14.

[20] Murnita PEM, Putra IMPD. 2018. Pengaruh Corporate Social Responsibility terhadap Nilai Perusahaan dengan Profitabilitas dan Leverage sebagai Variabel Pemoderasi. EJurnal Akuntansi Universitas Udayana. 23(2):1470-1494.

[21] Sihotang E, Angela LM, Wibowo AS. 2018. Analisis Pengaruh Kinerja Keuangan Terhadap Nilai Perusahaan dengan Pengungkapan Corporate Social Responsibility (CSR) sebagai Variabel Moderating (Studi empiris pada perusahaan manufaktur yang terdaftar di BEI pada tahun 2014- 2016).

[22] Pohan CD, Dwimulyani S. 2017. Analisis pengaruh kinerja keuangan, good corporate governance, dan corporate social responsibility terhadap nilai perusahaan pada perusahaan pertambangan di Bursa Efek Indonesia. Jurnal Magister Akuntansi Trisakti. 4(1):37-54.

[23] Abdillah W, Jogiyanto. 2015. Partial Least Square (PLS), Alternatif Structural Equation Modeling (SEM) Dalam Penelitian Bisnis. Yogyakarta(ID): CV Andi Offset.

[24] Schumacker RE, Lomaz RG. 2004. A Beginner's Guide to Structural Equation Modeling (2nd Edition). London (GB): Lawrence Erlbaum Assciates, Inc.

[25] Vinzi VE, Chin WW, Henseler J, Wang H. 2010. Handbook of Partial Least Square. London (GB): Springer Heidelberg Dordrecht.

[26] Hair JR, Sarstedt M, Hopkins L, Kuppelwieser VG. 2014. Partial least squares structural equation modeling (PLS-SEM): An emerging tool in business research. European Business Review. 26(2): 106-121.

[27] Hair JR, Wiliam C, Barry J, Rolph E. 2010. Multivariate Data Analysis (7th ed). New Jersey (US) : McGraw-Hill.

[28] Chin, Wynne W. 1998. The Partial Least Squares Approach to Structural Equation Modelling. London (GB) : Lawrence Erlbaum Associates.

[29] Sari WA, Handayani SR, Nuzula NF. 2016. Pengaruh Pengungkapan Corporate Social Responsibility terhadap Kinerja Keuangan dan Nilai Perusahaan (Studi Komparatif pada Perusahaan Multinasional yang Terdaftar di Bursa Efek Indonesia dan Bursa Malaysia Tahun 2012- 2015). Jurnal Administrasi Bisnis. 39(2):74-83. 
[30] Salehi M, DashtBayaz ML, Khorashadizadeh S. 2018. Corporate social responsibility and future financial performance: Evidance from Tehran Stock Exchange. Emerald Journal of Business. 13(3):351- 371.

[31] Akben-Selcuk E, 2019. Corporate Social Responsibility and Financial Performance: The Moderating Role of Ownership Concentration in Turkey. Sustainability.11.

[32] Christanti N, Mahastanti LA. 2011. Faktor-faktor yang dipertimbangkan investor dalam melakukan investasi. Jurnal Manajemen Teori dan Terapan. 4(3): 37-51.

[33] Janamrung B, Issarawornrawanich. 2015. The association between corporate social responsibility index and performance of firm in industrial products and resources industries: empirical evidence from Thailand. Social Responsibility Journal. 11(4):893903.

[34] Harningsih S, Agustin H, Setiawan MA. 2019. Pengaruh kinerja keuangan terhadap nilai perusahaan dengan pengungkapan csr dan kebijakan dividen sebagai variabel moderasi. Ranah Research Journal of Multidicsiplinary Research and Development. 1(2): 199-209.

[35] Brimantyo H, Rochman AK, Karima T. 2019. Peningkatan kinerja keuangan perusahaan melalui struktur modal untuk meningkatkan nilai perusahaan. Jurnal Bisnis dan Manajemen. 6(1): 6-14. 